\title{
Interest of Electrical Logging in Implementation of Technical Equipment for Water Drilling: Case of the Abrobakro Collecting Field (South-East Ivory Coast)
}

\author{
Kouassi Kouamé Auguste1 ${ }^{*}$, Douagui Gountôh Aristide1, Mangouaoi Mangoua Jules², \\ Coulibaly Kafana ${ }^{1}$, Kouassi Francis Williams ${ }^{1}$
}

${ }^{1}$ Geosciences and Environment Laboratory, UFR of Sciences and Environmental Management, Nangui Abrogoua University, Abidjan, Côte d'Ivoire

${ }^{2}$ UFR Environment, Laboratory of Environmental Sciences and Technologies, Jean Lorougnon Guedé Daloa University, Daloa, Côte d'Ivoire

Email: *kouameauguste@yahoo.fr

How to cite this paper: Auguste, K.K., Aristide, D.G., Jules, M.M., Kafana, C. and Williams, K.F. (2019) Interest of Electrical Logging in Implementation of Technical Equipment for Water Drilling: Case of the Abrobakro Collecting Field (South-East Ivory Coast). Journal of Power and Energy Engineering, 7, 28-34. https://doi.org/10.4236/jpee.2019.711003

Received: October 1, 2019

Accepted: November 15, 2019

Published: November 18, 2019

Copyright $\odot 2019$ by author(s) and Scientific Research Publishing Inc. This work is licensed under the Creative Commons Attribution International License (CC BY 4.0).

http://creativecommons.org/licenses/by/4.0/

\begin{abstract}
This work concerns the collecting field of the Abrobakro site, the objective of which is to determine the thickness of the layers crossed during drilling from electrical logging in order to propose the equipment plan for the various boreholes. The electrical logging data sheets, particularly those on resistivity and expeditious granulometry using a $1.25 \mathrm{~mm}$ and $2 \mathrm{~mm}$ mesh sieve, were used. The layer thicknesses are determined with the inflection points on the graphs. The electrical logging shows that the sands in the study area have resistivity values between 400 and $5000 \Omega$.m. The decrease in resistivity observed at 50 $\mathrm{m}$ for all boreholes shows that the static level of the groundwater is at this depth. The results of the accelerated granulometry show that the first 20 meters contain more fine particles and coarse to very coarse sands from $20 \mathrm{~m}$. The granulometry of the screen laying areas shows that the $1.5 \mathrm{~mm}$ slot openings are best suited for all drilling in the Abrobakro collecting field. The diameter $\mathrm{d}_{10}$ of the aquiferous sands of the collecting field is close to $1.25 \mathrm{~mm}$.
\end{abstract}

\section{Keywords}

Electrical Well Logging, Water Drilling, Abrobakro, Ivory Coast

\section{Introduction}

Groundwater exploitation requires drilling. Once the drilling is completed, the 
casing and well screen must be installed at the correct depth to ensure sufficient flow [1]. For the installation of the technical equipment, the project owners choose to analyze the drilling cuttings. The analysis of drilling cuttings is a source of inaccuracy as there are many factors that interfere with their ascent into the drilling mud. The margin of error can exceed $10 \mathrm{~m}$ [2]. The use of electrical measurements in drilling makes it the best way to carry out the technical equipment plan, which has a beneficial impact on the operating flow rate and the risk of clogging. The logging method has been developed for oil exploration to provide continuous recording of rock properties for the identification and characterization of gas, oil and aquifer reservoirs [3]. The sampling step depends on the operator and the desired accuracy [4]. To date, the use of electrical well logging in water drilling in Ivory Coast remains a minority since drilling is often carried out in emergency contexts. This situation would cause the early damage and pollution of the boreholes [5]. It is in this context of optimization of well equipment that this study is part of, which aims to show the interest of electrical well logging in the implementation of technical equipment for water drilling.

The department of Bonoua is located in the south-East of Ivory Coast. It is between latitudes 560,000 and 590,000 $\mathrm{m}$ and longitudes 421,000 and 461,000 m (Figure 1). The Bonoua region covers an area of $1350 \mathrm{~km}^{2}$ and has a plain relief with altitudes below $200 \mathrm{~m}$, characteristic of southern Ivory Coast [6]. The department of Bonoua is administratively limited by the departments of Aboisso and Adiaké in the east, Alépé and Grand Bassam in the west, Gulf of Guinea in the south and Assinie Mafia in the south. The study area is located precisely in the town of Abrobakro, 10.4 kilometres from Bonoua in the Samo sub-prefecture. Geologically and hydrogeologically, the study area is mostly located in the sedimentary basin (Figure 1). The main formation of the study area is that of the Continental Terminal of Mio-Pliocene age [7]. To the south, the granit sink is covered by a sometimes thick layer of clayey sands. On the coast and on the shores of the Aby lagoon, Quaternary formations appear [6]. The region is crossed by the Comoé River, the Bia and Mé Rivers [8]. The study area is located mostly in the sedimentary basin and is well watered with an average annual rainfall of $1710 \mathrm{~mm}$.

\section{Materials and Methods}

\subsection{Materials and Data}

The data used come from the Abrobakro wellfield drillings, of which the data presented are from well F03. These are electrical resistivity data measured with a normal large probe, lithology data and accelerated particle size data using 1, 25 $\mathrm{mm}$ and $2 \mathrm{~mm}$ mesh sieves. For the measurement of the resistivity the normal probe is lowered into the borehole every $1 \mathrm{~m}$ and the resistivity is measured in front of the layer. In terms of grain size, we take a $75 \mathrm{~g}$ sample every $1 \mathrm{~m}$ during the drilling and drying process and pass it through the meshes of the sieve. The percentage of rejection is thus calculated after this operation. 


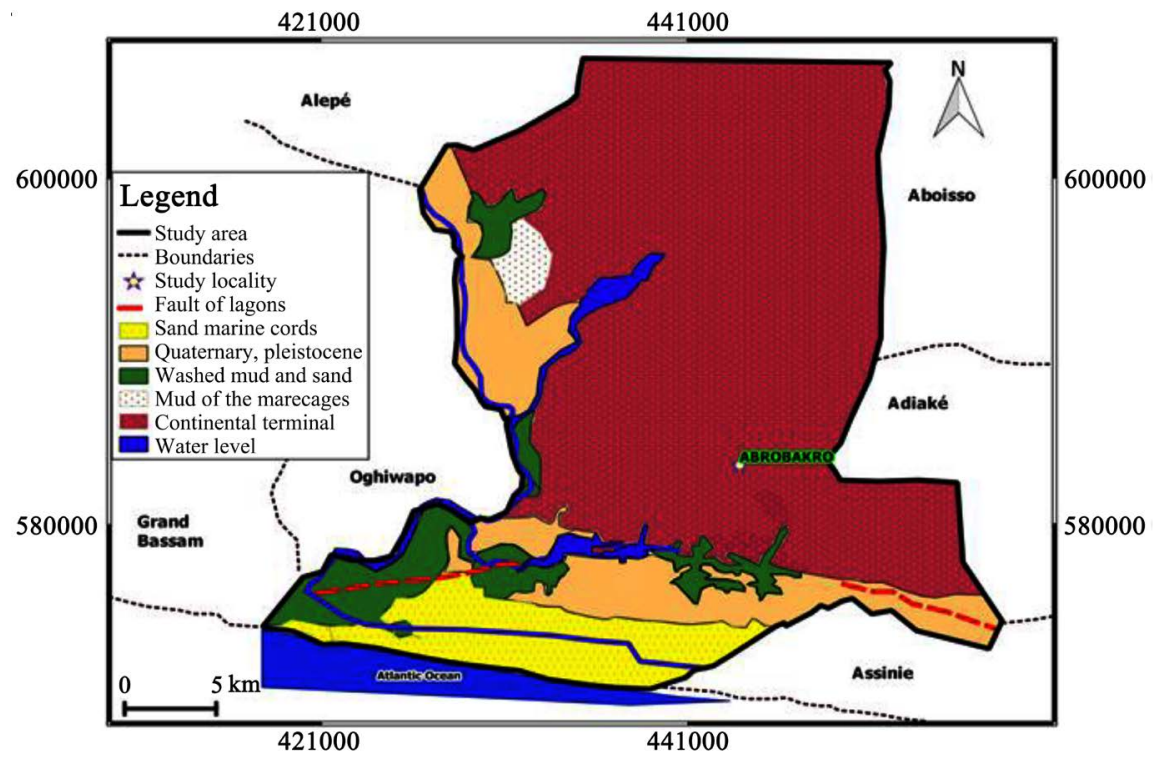

Figure1. Geological and hydrogeological map of the area of Bonoua [8] modified.

\subsection{Methods}

\section{Determination of layer thickness}

The resistivity data for each well was graphically represented with the resistivity as a function of the drilling depths. The thickness of the layer is determined on the resistivity graph at the inflection points of the curve [9] [10]; while the lithological section was used to specify the nature of the rocks.

\section{Identification of the installation dimensions of well screen}

Screens should be placed in horizons where the particles are coarse. Coarse formations are determined by representing the percentage of screen refusals of $1.25 \mathrm{~mm}$ and $2 \mathrm{~mm}$ in diameter as a function of the drilling depth. Coarse formations are areas with high rejection rates on the graphs. To identify the horizons for filter installation, the coarse formations located at depth with a high thickness were chosen.

\section{Choice of filter gravel and well screen openings}

The choice of the opening of the strainers and the size of the grains of the filter gravel mass is made according to the granulometry of the aquifer. In our study, this choice was made on the basis of Table 1 [11], which shows the correspondence between the granulometry of the aquifer, the gravel massif and the opening of the strainers.

\section{Results and Discussion}

\subsection{Thicknesses Determination}

The electrical resistivity logging of borehole F03 was recorded between 10 and $154 \mathrm{~m}$ deep (Figure 2). The graph shows that the layers are resistant between 10 and 50 meters deep and this resistance of the layers is explained by the fact that they are dry. At this depth, the resistance of medium to coarse dry sands is be- 
tween 1600 and $2500 \Omega$.m. Above a depth of 50 meters, resistivity becomes low, which is caused by water saturation [11] of the layers. The resistivity of coarse sands is between 1000 and $1300 \Omega$.m. and between 900 and $1000 \Omega . m$. for medium to coarse sands.

The graph (Figure 2) shows that 6 layers were crossed during drilling. The layer of coarse sand located between 106 and $154 \mathrm{~m}$ deep at a higher thickness $(48 \mathrm{~m})$ than the other layers and is saturated with water. This layer is therefore more suitable for the installation of well screen. Table 2 below summarizes the thicknesses of the layers traversed and the resistivity ranges measured.

\subsection{Evolution of Granulometry}

The grain size analysis graph shows three areas (Figure 3 ). A first zone from 0 to $18 \mathrm{~m}$ deep where the refusal percentages are $1.33 \%$ for the $1.25 \mathrm{~mm}$ sieve (green curve) and $0.13 \%$ for the $2 \mathrm{~mm}$ sieve (red curve). In the second zone from 18 to $90 \mathrm{~m}$, there is an increase in the percentage of refusals for both screens. Above $100 \mathrm{~m}$ depth, the high percentages (30\% to $80 \%$ ) for the $1.25 \mathrm{~mm}$ sieve and $(10 \%$ to $50 \%$ ) for the $2 \mathrm{~mm}$ sieve are observed. The high rejection rates show that the sand in this area is very coarse and facilitates the hydraulic connection of the groundwater.

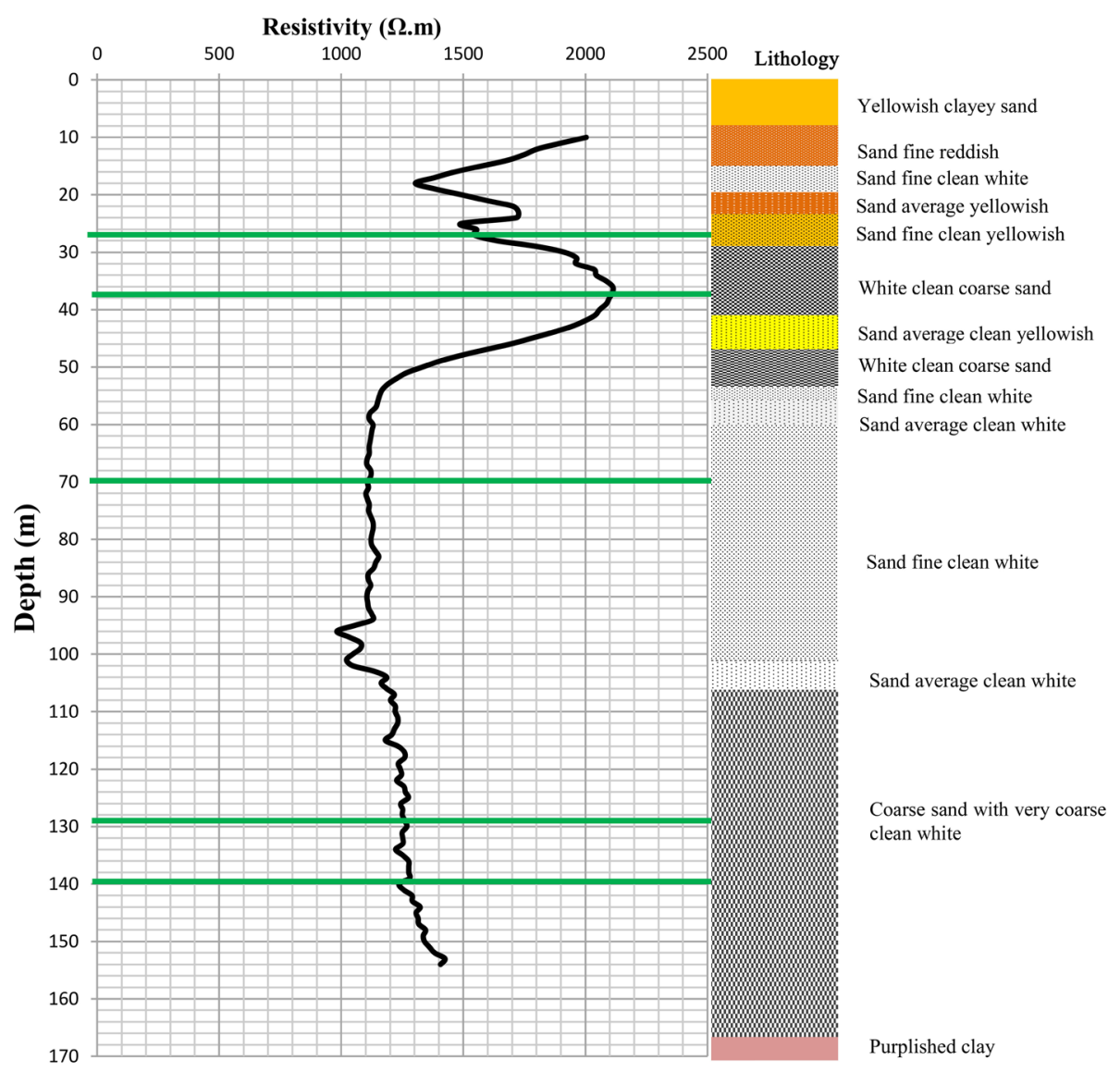

Figure 2. Thickness determination on log of resistivity. 


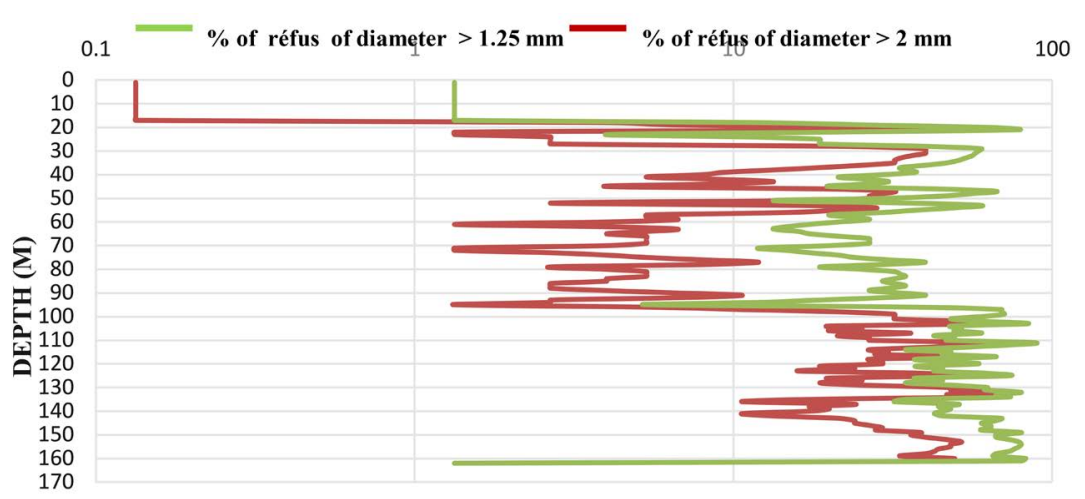

Figure 3. Graph showing the evolution of granulometry with the depth.

Table 1. Cut grains aquifer and openings of well screen [11].

\begin{tabular}{ccc}
\hline $\begin{array}{c}\text { Cut grains } \\
\text { Aquifer }\end{array}$ & $\begin{array}{c}\text { Cut grains of the } \\
\text { gravel filters }\end{array}$ & $\begin{array}{c}\text { Cut openings of the well } \\
\text { screen }\end{array}$ \\
\hline 0.1 to $0.6 \mathrm{~mm}$ & 0.7 to $1.2 \mathrm{~mm}$ & $0.5 \mathrm{~mm}$ \\
0.2 to $0.8 \mathrm{~mm}$ & 0.1 to $0.5 \mathrm{~mm}$ & $0.75 \mathrm{~mm}$ \\
0.3 to $1.2 \mathrm{~mm}$ & 1.5 to $2.0 \mathrm{~mm}$ & $1.00 \mathrm{~mm}$ \\
0.4 to $2.0 \mathrm{~mm}$ & 1.7 to $2.5 \mathrm{~mm}$ & $1.50 \mathrm{~mm}$ \\
0.5 to $3.0 \mathrm{~mm}$ & 3.0 to $4.0 \mathrm{~mm}$ & $2.00 \mathrm{~mm}$ \\
\hline
\end{tabular}

Table 2. Summary of thicknesses determination.

\begin{tabular}{cccc}
\hline Layer & Depth $(\mathrm{m})$ & Thickness $(\mathrm{m})$ & Resistivity $(\Omega . \mathrm{m})$ \\
\hline Sand fine argillaceous yellow & 10 to 18 & 8 & 1300 to 2000 \\
Sand fine with average yellow & 18 to 27 & 9 & 1550 \\
White coarse sand & 27 to 50 & 23 & 2112 \\
Sand fine white & 50 to 94 & 44 & 1130 \\
Sand average clean white & 94 to 106 & 12 & 980 to 1085 \\
Coarse sand with very coarse & 106 to 154 & 48 & 1180 to 1450 \\
\hline
\end{tabular}

\subsection{Technical Equipment Plan}

In addition, this high rejection rate shows that this layer of coarse sand contains less fine particles that would cause clogging of well screen. The graph shows that the percentages of refusals are high at the coarse sand layer between 100 and 154 $\mathrm{m}$. The well screen are therefore placed in relation to the coarse sands between $104 \mathrm{~m}$ and $150 \mathrm{~m}$ (Figure 4). The gravel bed is placed between 100 and $156 \mathrm{~m}$ and the entire solid casing will be placed between 0 and $102 \mathrm{~m}$. The choice of coarse to very coarse sand is due to the fact that it has a high effective porosity and a high porosity of $d_{10}$. According to [12], when the effective grain size is less than $0.25 \mathrm{~mm}$, the sand becomes difficult to screen, but when the grain size increases, screening and grading are more efficient, permeability increases and the flow rate provided by a thickness of sand also increases the chosen area (104 to $150 \mathrm{~m}$ ) has an effective grain size of $1.25 \mathrm{~mm}$ that is greater than $0.25 \mathrm{~mm}$. The effective porosity of coarse sand is $34 \%$ and the $\mathrm{d} 10$ is $0.25 \mathrm{~mm}$ while the average gravel has an effective porosity of $40 \%$ for a $d_{10}$ of $2.5 \mathrm{~mm}$ [13]. When the $d_{10}$ is high, it allows a wide choice of wells screen openings and facilitates the installation of filter gravel. 


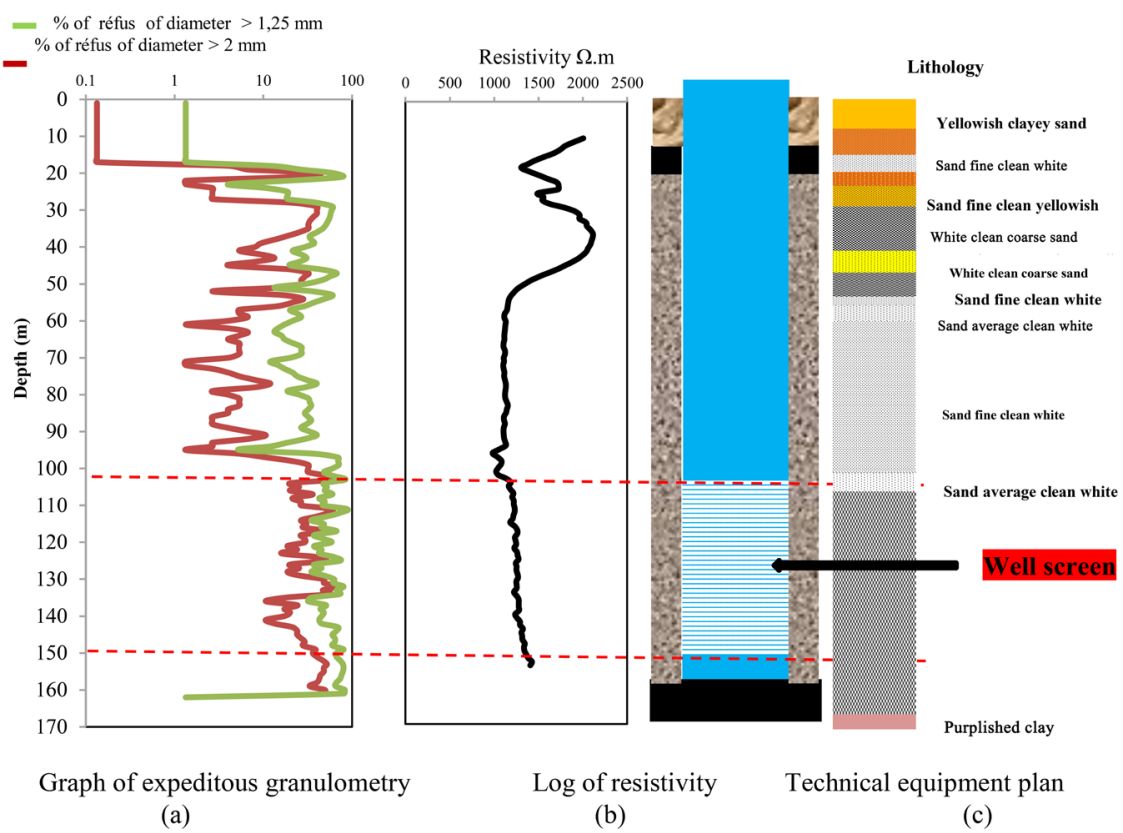

Figure 4. Choice of the screened area of the FO3 borehole from the expedited granulometry and electrical logging graph.

The graph of the drilling granulometry shows that the $d_{10}$ is close to $1.25 \mathrm{~mm}$ and therefore that the sand grains are very coarse and can be used as filter gravel. According to [13] when the $d_{10}$ is greater than $0.25 \mathrm{~mm}$ the aquifer formation can be used as filter gravel. Referring to Table 1 [11], the $1.5 \mathrm{~mm}$ slot openings are best suited for capturing the coarse sand layer of FO3 drilling.

\section{Conclusion}

The use of electrical well logging and expeditious granulometry is important in technical equipment plan of boreholes and especially in the installation of wells screens. The thickness of the layers and the resistivity ranges are determined more accurately than the analysis of the drilling debris. Thus for FO3 drilling, very coarse saturated sands have a resistivity ranging from 1000 to $1300 \Omega$.m. and this resistivity range corresponds to high refusal percentages of between $30 \%$ and $80 \%$ on graphs. The combined use of electrical logging and expedited granulometry optimizes the installation of technical equipment plan of water borehole.

\section{Acknowledgements}

This research was supported by the Hydrogeology Research Group of the Geosciences and Environment Laboratory of Nangui Abrogoua University in Abidjan, Ivory Coast. The constructive and valuable comments of the anonymous readers and the Editor-in-Chief of the Journal are greatly appreciated. The authors also thank Dr. KOUASSI Francis Williams for providing us with the data from this research. 


\section{Conflicts of Interest}

The authors declare no conflicts of interest regarding the publication of this paper.

\section{References}

[1] Arjen, V. (2010) Connaissances des méthodes de captage des eaux souterraines. Fondation pratica, $49 \mathrm{p}$.

[2] Maget, Ph. (2008) Drilling Logs Initiation into Method and Interpretation, Application in Geothermal Energy.

[3] Taillet, E. (2013) Characterization of Discontinuities in Massive Concrete Structures by Electrical Resistivity Logging. Ph.D. Thesis, University.

[4] Beck, M., Girardet, D., Chapellier, D. and Descloitres, M. (2001) Electrical Logs for the Optimization of Hydrofracturing in the Basement Area. First Results in Burkina Faso, GEOFCAN Symposium, Orléans, 25-26 September 2001.

[5] Aké, G., Kouadio, K.A., Bernard, D.K. and Patrice, J.J. (2017) Perimeters of Protection Demarcation for New Boreholes of Bonoua Aquifer (Southeastern, Côte d'Ivoire) through Hydrogeological Modeling. Journal of Geoscience and Environment Protection, 5, 118-138. https://doi.org/10.4236/gep.2017.511009

[6] Jourda, J.P, Kouame, K.J, Adja, M.G, Deh, S.K, Anani, A.T, Effini, A.T. and Biemi, J. (2007) Evaluation du degré de protection des eaux souterraines : vulnérabilité à la pollution de la nappe de Bonoua (Sud-Est de la Côte d'Ivoire) par la méthode DRASTIC. https://www.esrifrance.fr/sig2007/cocody_jourda.htm

[7] Tastet, J.P. (1979) Environnements sédimentaires et structuraux quaternaires du littoral du golfe de Guinée, Côte d'Ivoire, Togo, Bénin. Ph.D. Thèse, Université, Bordeau I.

[8] Desbrandes, R. (1968) Théorie et interprétation des diagraphies. Sciences et Technique du Petrole No. 13.

[9] Serra, O. (1979) Diagraphies différées: Bases de l'interprétation, Tome 1: Acquisition des données diagraphiques. Elf Exploration édition Paris, 324 p.

[10] Kouamé, L.N., Sombo, B.C., Digbehi, Z.B., Sombo, A.P., Kouassi, G. and Essoh, A.S. (2011) Relations vitesse sismique et propriétés pétrophysiques des terrains sédimentaires dans la marge continentale de Côte d'Ivoire. Geo-Eco-Trop, 35, 9-22.

[11] Castany, G. (1982) Principe et méthodes de l'hydrogéologie. Dunod, Paris, 238 p.

[12] Alger, R.P. (1966) Interpretation of electric log in fresh water wells in unconsolidated formation. $7^{\text {th }}$ Annual Logging Symposium, Houston, 9-11.

[13] Hazen, A. (1892) Some Physical Properties of Sands and Gravels, with Special Reference to Their Use in Filtration. 24th Annual Report, Massachusetts State Board of Health, 539-556. 